\title{
Nocardioides oleivorans sp. nov., a novel crude-oil-degrading bacterium
}

Correspondence

Axel Schippers

A.Schippers@bgr.de

\author{
Axel Schippers, ${ }^{1}$ Peter Schumann ${ }^{2}$ and Cathrin Spröer ${ }^{2}$ \\ ${ }^{1}$ Referat Geomikrobiologie, Bundesanstalt für Geowissenschaften und Rohstoffe, Stilleweg 2, \\ D-30655 Hannover, Germany \\ ${ }^{2}$ DSMZ - Deutsche Sammlung von Mikroorganismen und Zellkulturen, Mascheroder Weg $1 \mathrm{~b}$, \\ D-38124 Braunschweig, Germany
}

The crude-oil-degrading strain BAS3 $^{\top}$ represents a novel Nocardioides species, according to a taxonomic study. The $16 \mathrm{~S}$ rRNA gene sequence of strain $\mathrm{BAS}^{\top}$ was most similar to that of Nocardioides ganghwensis (IMSNU $14028^{\top}$; $99 \%$ similarity), but the DNA-DNA relatedness to this type strain was only $32 \%$. The physiological properties of strain BAS3 ${ }^{\top}$ differ from those of N. ganghwensis (IMSNU 14028 ${ }^{\top}$ ) and other species of Nocardioides. The diamino acid in the cell-wall peptidoglycan of strain $B A S 3^{\top}$ is LL-diaminopimelic acid and the major menaquinone is MK-8 $\left(\mathrm{H}_{4}\right)$. The name Nocardioides oleivorans sp. nov. is proposed for the novel Nocardioides species, since its type strain, BAS3 ${ }^{\top}\left(=\mathrm{DSM} 16090^{\top}=\mathrm{NCIMB} 14004^{\top}\right)$, is able to degrade crude oil.
Crude oil consists of various hydrocarbons that can be degraded by micro-organisms (Jobson et al., 1972; Bosecker et al., 1991; Zengler et al., 1999). Several genera of hydrocarbon-oxidizing bacteria are known (Rosenberg, 2000; Van Hamme et al., 2003). The aromaticcompound-degrading species of the genus Nocardioides comprise the pyridine-degrading species Nocardioides pyridinolyticus (Yoon et al., 1997), the p-nitrophenoldegrading species Nocardioides nitrophenolicus (Yoon et al., 1999 ) and the pyric acid (2,4,6-trinitrophenol)-degrading Nocardioides species strain CB 22-2 (Rajan et al., 1996; Behrendt \& Heesche-Wagner, 1999).

Here we describe the classification of the crudeoil-degrading strain $\mathrm{BAS}^{\mathrm{T}}$ as a member of the genus Nocardioides. The Gram-positive strain was isolated from crude oil sample 19 from the oilfield Oerrel of the Gifhorn Trough, North-West Germany (Bosecker et al., 1991). For enrichment, artificial sea-water medium, supplemented with $1-5 \%(\mathrm{w} / \mathrm{v})$ crude oil as the carbon source, in Erlenmeyer flasks was inoculated and incubated on a rotary shaker at $30{ }^{\circ} \mathrm{C}$ in the dark for several weeks. The medium $(\mathrm{pH} 7 \cdot 3)$ consisted of the following $\left(1^{-1}\right): 23.4 \mathrm{~g} \mathrm{NaCl}$, $0.75 \mathrm{~g} \mathrm{KCl}, 7 \cdot 0 \mathrm{~g} \mathrm{MgSO}_{4} .7 \mathrm{H}_{2} \mathrm{O}, 1.0 \mathrm{~g} \mathrm{NH}_{4} \mathrm{NO}_{3}, 0.7 \mathrm{~g}$ $\mathrm{K}_{2} \mathrm{HPO}_{4}$ and $0.3 \mathrm{~g} \mathrm{KH}_{2} \mathrm{PO}_{4}$ (Fedorak \& Westlake, 1981).

Published online ahead of print on 4 March 2005 as DOI 10.1099/ ijs.0.63500-0.

The GenBank/EMBL/DDBJ accession number for the 16S rRNA gene sequence of strain BAS3 ${ }^{\top}$ is AJ698724.

A phylogenetic tree for strain $\mathrm{BAS}^{\top}$ along with a table of its whole-cell fatty acid composition are available as supplementary material in IJSEM Online.
For isolation via subculturing on agar plates, a basal medium $(\mathrm{pH} 7 \cdot 3)$, without oil, was used, consisting of the following $\left(\mathrm{l}^{-1}\right): 23.4 \mathrm{~g} \mathrm{NaCl}, 0 \cdot 75 \mathrm{~g} \mathrm{KCl}, 7 \cdot 0 \mathrm{~g} \mathrm{MgSO}_{4} .7 \mathrm{H}_{2} \mathrm{O}$, $0.5 \mathrm{~g}$ peptone from meat, $0.5 \mathrm{~g}$ peptone from casein, $1.0 \mathrm{~g}$ yeast extract and $18 \mathrm{~g}$ agar.

The morphology of the cells, their motility and the occurrence of spores were investigated by using phasecontrast light microscopy (Axioskop microscope; Zeiss). A Gram-stain and a test for catalase were performed according to Burghardt (1992) and Gerhardt et al. (1994). Anaerobic growth was checked by means of incubation in the presence and absence of oxygen, using the Anaerocult system (Merck). Further physiological tests were carried out as described by Kämpfer et al. (1991). Briefly, the utilization of various carbon sources as sole substrate and the hydrolysis of various compounds were studied using a complex medium containing trace elements and vitamins in microplates. To confirm oil degradation, $40 \mathrm{ml}$ medium (Kämpfer et al., 1991; modified) in $100 \mathrm{ml}$ Erlenmeyer flasks was supplemented with $1 \mathrm{ml}$ crude oil as the sole carbon source, inoculated and then incubated on a rotary shaker (120 r.p.m.) at $25^{\circ} \mathrm{C}$. Cell growth was checked after 3 weeks. The modified medium had a $\mathrm{pH}$ of $7 \cdot 0$ and the following composition $\left(\mathrm{l}^{-1}\right): 1 \cdot 0 \mathrm{~g} \mathrm{NaCl}, 0 \cdot 1 \mathrm{~g} \mathrm{MgSO}_{4} .7 \mathrm{H}_{2} \mathrm{O}$, $1.0 \mathrm{~g}\left(\mathrm{NH}_{4}\right)_{2} \mathrm{SO}_{4}, 3 \cdot 2 \mathrm{~g} \mathrm{~K}_{2} \mathrm{HPO}_{4}, 6 \cdot 18 \mathrm{~g} \mathrm{Na}_{2} \mathrm{HPO}_{4} \cdot 2 \mathrm{H}_{2} \mathrm{O}$, $0.17 \mathrm{~g} \mathrm{CaSO}_{4} .2 \mathrm{H}_{2} \mathrm{O}, 0.001 \mathrm{~g} \mathrm{H}_{3} \mathrm{BO}_{3}, 0.002 \mathrm{~g} \mathrm{CuSO}_{4} .5 \mathrm{H}_{2} \mathrm{O}$, $0.003 \mathrm{~g} \quad \mathrm{ZnI}_{2} .8 \mathrm{H}_{2} \mathrm{O}, \quad 0.2 \mathrm{~g} \quad \mathrm{FeSO}_{4} .7 \mathrm{H}_{2} \mathrm{O}, \quad 0.002 \mathrm{~g}$ $\mathrm{NiCl}_{2} \cdot 6 \mathrm{H}_{2} \mathrm{O}, 0.004 \mathrm{~g} \mathrm{CoCl} \cdot 6 \mathrm{H}_{2} \mathrm{O}, 0.01 \mathrm{~g} \mathrm{MnCl}_{2} .5 \mathrm{H}_{2} \mathrm{O}$, $0.003 \mathrm{~g} \mathrm{Na}_{2} \mathrm{MoO}_{4} .2 \mathrm{H}_{2} \mathrm{O}, 0.5 \mathrm{~g}$ EDTA. $2 \mathrm{H}_{2} \mathrm{O}$ and vitamins according to Kämpfer et al. (1991).

The occurrence of diaminopimelic acid in the cell wall and 
also the peptidoglycan type were determined as described by Schleifer (1985) and Schleifer \& Kandler (1972), using TLC with cellulose plates (Merck). Menaquinones were extracted as described by Collins et al. (1977) and were analysed by HPLC according to Groth et al. (1996). Analysis of the whole-cell fatty acid pattern of cells grown on the basal medium was performed with the MIDI system (Microbial ID), using previously described methods (Kroppenstedt, 1985; Meier et al., 1993).

Genomic DNA extraction, PCR-mediated amplification of the 16S rRNA gene and purification of PCR products were carried out as described previously (Rainey et al., 1996). Purified PCR products were sequenced with Taq DyeDeoxy terminator cycle sequencing kits (Applied Biosystems) according to the manufacturer's protocol. An Applied Biosystems 373A DNA sequencer was used for electrophoresis of the sequence reaction products. The ae2 editor (Maidak et al., 1999) was used to align the 16S rRNA gene sequence determined in this study against the 16S rRNA gene sequences (available from the public databases) of representatives of the main bacterial lineages. Pairwise evolutionary distances were computed using the correction of Jukes \& Cantor (1969). The least-squares distance method of De Soete (1983) contained in the PHYLIP package (Felsenstein, 1993) was used in the construction of the phylogenetic dendrogram from distance matrices. Bootstrap analyses were done as described by Felsenstein (1993).

For DNA-DNA reassociation experiments, DNA was isolated using a French pressure cell (Thermo Spectronic) and purified by chromatography on hydroxyapatite, as described by Cashion et al. (1977). DNA-DNA hybridization was carried out under optimal conditions for DNA-DNA reassociation as described by De Ley et al. (1970), with the modifications described by Huß et al. (1983), using a Cary 100 Bio UV/VIS spectrophotometer equipped with a Peltierthermostatted $6 \times 6$ multicell changer and a temperature controller with an in situ temperature probe (Varian).

The almost-complete 16S rRNA gene sequence of strain $\mathrm{BAS}^{\mathrm{T}}$ was compared with those of members of closely related genera. Members of the genus Nocardioides were the closest phylogenetic neighbours. A maximum pairwise similarity value of $99 \%$ was found for Nocardioides ganghwensis IMSNU $14028^{\mathrm{T}}$. Pairwise similarity values higher than $95 \%$ were also found for Nocardioides aquiterrae KCCM $41647^{\mathrm{T}}(95 \cdot 4 \%)$, N. pyridinolyticus KCTC $0074 \mathrm{BP}^{\mathrm{T}}(95 \cdot 2 \%)$, Nocardioides simplex KCTC $9106^{\mathrm{T}}$ $(95 \cdot 2 \%)$ and N. nitrophenolicus KCTC $0457 \mathrm{BP}^{\mathrm{T}}(95 \cdot 1 \%)$; a phylogenetic tree of the Nocardioides species and species of closely related genera is available as supplementary material in IJSEM Online.

Because of the high pairwise similarity value (99\%) between strain $\mathrm{BAS}^{\mathrm{T}}$ and N. ganghwensis, the DNA-DNA relatedness of these two strains was determined. The value obtained was $32 \%$, which is well below the threshold value of $70 \%$ recommended for the definition of bacterial species (Wayne et al., 1987).

The morphological, physiological and chemotaxonomic characteristics of strain BAS3 ${ }^{\mathrm{T}}$ were analysed. The properties are given in the description section. Several physiological properties of strain $\mathrm{BAS}^{\mathrm{T}}$ and the closest phylogenetic neighbour, N. ganghwensis IMSNU $14028^{\mathrm{T}}$ (Yi \& Chun, 2004), were compared. For the latter strain, oil degradation could not be observed, and the following carbon sources were utilized by this strain only: citrate, salicin and Larabinose. L-Rhamnose, however, was utilized only by strain $\mathrm{BAS}^{\mathrm{T}}{ }^{\mathrm{T}}$. Both strains utilized D-cellobiose, D-fructose, Dgalactose, D-glucose, D-mannose, L-ornithine and $\mathrm{N}$ acetylglucosamine.

The fatty acid profile of strain $\mathrm{BAS}^{\mathrm{T}}$ was characteristic of members of the genus Nocardioides (iso- $\mathrm{C}_{16: 0}$ as the branched fatty acid plus an abundance of 10-methyl fatty acids). The major fatty acids of strain $\mathrm{BAS}^{\mathrm{T}}$ were $\mathrm{C}_{18: 1} \omega 9 c$, iso- $\mathrm{C}_{16: 0}, \mathrm{C}_{18: 0}$ and 10-methyl fatty acids (the whole-cell fatty acid composition of strain BAS3 ${ }^{\mathrm{T}}$ and those of closely related Nocardioides type strains are available as a supplementary table in IJSEM Online). Strain BAS3 ${ }^{\mathrm{T}}$ contained LL-diaminopimelic acid in the cell wall and had A3 $\gamma$-type peptidoglycan (LL-diaminopimelic acid-Gly). MK-8 $\left(\mathrm{H}_{4}\right)$ was the major menaquinone and $\mathrm{MK}-8\left(\mathrm{H}_{2}\right)$ was a minor menaquinone component.

On the basis of the polyphasic evidence, we suggest that strain $\mathrm{BAS}^{\mathrm{T}}$ represents a novel species, for which we propose the name Nocardioides oleivorans sp. nov.

\section{Description of Nocardioides oleivorans sp. nov.}

Nocardioides oleivorans [o.le.i.vor' ans. L. n. oleum oil; L. v. vorare to devour; N.L. part. adj. oleivorans capable of utilizing oil (hydrocarbons)].

Cells are obligate aerobic, Gram-positive, non-endosporeforming, non-motile, irregular rods about $0 \cdot 3 \mu \mathrm{m}$ wide and up to $1 \cdot 1 \mu \mathrm{m}$ long. Catalase-positive and oxidase-negative. Colonies are circular, smooth, translucent and orangepigmented with a maximum colony diameter of $2 \mathrm{~mm}$ after 2 weeks. Growth occurs at $30^{\circ} \mathrm{C}$ and with $2 \%(\mathrm{w} / \mathrm{v})$ $\mathrm{NaCl}$. Crude oil is used as substrate. Acid is not produced from D-glucose, rhamnose, sucrose, adonitol, inositol, xylose or sorbitol. Utilization of $\mathrm{N}$-acetylD-glucosamine, D-cellobiose, D-fructose, D-galactose, gluconate, D-glucose, D-maltose, D-mannose, $\alpha$-Dmelibiose, L-rhamnose, D-sucrose, D-trehalose, D-mannitol, acetate, propionate, fumarate, DL-3-hydroxybutyrate, DL-lactate, L-malate, pyruvate, L-aspartate, L-histidine, L-proline, putrescine, phenylacetate and L-ornithine is observed. L-Arabinose, $\alpha$-D-galacturonate, glycogen, D-ribose, salicin, L-xylose, adonitol, i-inositol, sorbitol, trans-aconitate, adipate, citrate, suberate, L-alanine, L-hydroxyproline, L-serine, 3-hydroxybenzoate, 4hydroxybenzoate and $\mathrm{N}$-acetyl-D-galactosamine are not 
utilized. Hydrolysis of $p$-nitrophenyl (pNP) $N$-acetyl$\beta$-D-glucosaminide, pNP $\beta$-D-galactopyranoside, $\mathrm{pNP}$ $\alpha$-D-glucopyranoside, pNP $\beta$-D-glucopyranoside, pNP $\alpha$ D-maltoside, bis-pNP phosphate, benzolphosphonacid pNP-ester, pNP phosphocholine, 2-desoxythymidine $5^{\prime}$ pNP phosphate, L-alanine $p$-nitroanilide (pNA), $\gamma$-Lglutamate pNA, L-glutamate- $\gamma$-3-carboxy pNA, L-leucine pNA and L-lysine pNA is detected. pNP $N$-acetyl- $\beta$-Dgalactosaminide, $\mathrm{pNP} \alpha$-L-arabinopyranoside, $\mathrm{pNP} \beta$-Dcellobioside, pNP $\beta$-D-glucuronide, pNP $\beta$-D-lactoside, pNP $\alpha$-D-mannoside, pNP $\beta$-D-xyloside, glycine pNA, Lproline pNA and L-valine pNA are not hydrolysed. The strain contains LL-diaminopimelic acid in its cell wall and possesses A3 $\gamma$-type peptidoglycan (LL-diaminopimelic acid-Gly). The cellular fatty acids comprise saturated, unsaturated, iso-, anteiso- and 10-methyl-branched types and hydroxy fatty acids. The major fatty acids are $\mathrm{C}_{18: 1} \omega 9 c$, iso- $\mathrm{C}_{16: 0}, \mathrm{C}_{18: 0}$ and 10-methyl fatty acids. The major menaquinone is $\mathrm{MK}-8\left(\mathrm{H}_{4}\right)$.

The type strain is strain $\mathrm{BAS3}^{\mathrm{T}}\left(=\mathrm{DSM} 16090^{\mathrm{T}}=\mathrm{NCIMB}\right.$ $14004^{\mathrm{T}}$ ), which was isolated from a crude oil sample from the oilfield Oerrel of the Gifhorn Trough, North-West Germany (Bosecker et al., 1991).

\section{Acknowledgements}

We thank Cornelia Haveland, Ina Kramer, Bettina Sträubler, Anika Vester, Marie-Anne Lepler and Daniela Zoch for excellent technical assistance.

\section{References}

Behrendt, U. \& Heesche-Wagner, K. (1999). Formation of hydrideMeisenheimer complexes of picric acid (2,4,6-trinitrophenol) and 2,4-dinitrophenol during mineralization of picric acid by Nocardioides sp. strain CB 22-2. Appl Environ Microbiol 65, 1372-1377.

Bosecker, K., Teschner, M. \& Wehner, H. (1991). Biodegradation of crude oils. In Developments in Geochemistry 6: Diversity of Environmental Biogeochemistry, pp. 195-204. Edited by J. Berthelin. Amsterdam: Elsevier.

Burghardt, F. (1992). Mikrobiologische Diagnostik. Stuttgart: Thieme. Cashion, P., Hodler-Franklin, M. A., McCully, J. \& Franklin, M. (1977). A rapid method for base ratio determination of bacterial DNA. Anal Biochem 81, 461-466.

Collins, M. D., Pirouz, T., Goodfellow, M. \& Minnikin, D. E. (1977) Distribution of menaquinones in actinomycetes and corynebacteria. J Gen Microbiol 100, 221-230.

De Ley, J., Cattoir, H. \& Reynaerts, A. (1970). The quantitative measurement of DNA hybridization from renaturation rates. Eur J Biochem 12, 133-142.

De Soete, G. (1983). A least squares algorithm for fitting additive trees to proximity data. Psychometrika 48, 621-626.

Fedorak, P. M. \& Westlake, D. W. S. (1981). Microbial degradation of aromatics and saturates in Prudhoe Bay crude oil as determined by glass capillary gas chromatography. Can J Microbiol 27, 432-443.

Felsenstein, J. (1993). PHYLIP (Phylogeny Inference Package), version 3.5c. Department of Genome Sciences, University of Washington, Seattle, USA.
Gerhardt, P., Murray, R. G. E., Wood, W. A., Hodson, R. E. \& Whitman, W. B. (1994). Methods for General and Molecular Bacteriology. Washington, DC: American Society for Microbiology.

Groth, I., Schumann, P., Weiss, N., Martin, K. \& Rainey, F. A. (1996). Agrococcus jenensis gen. nov., sp. nov., a new genus of actinomycetes with diaminobutyric acid in the cell wall. Int J Syst Bacteriol 46, 234-239.

Huß, V. A. R., Festl, H. \& Schleifer, K. H. (1983). Studies on the spectrophotometric determination of DNA hybridization from renaturation rates. Syst Appl Microbiol 4, 184-192.

Jobson, A., Cook, F. D. \& Westlake, D. W. S. (1972). Microbial utilization of crude oil. Appl Microbiol 23, 1082-1089.

Jukes, T. H. \& Cantor, C. R. (1969). Evolution of protein molecules. In Mammalian Protein Metabolism, pp. 21-132. Edited by H. N. Munro. New York: Academic Press.

Kämpfer, P., Steiof, M. \& Dott, W. (1991). Microbiological characterization of a fuel-oil contaminated site including numerical identification of heterotrophic water and soil bacteria. Microb Ecol 21, 227-251.

Kroppenstedt, R. M. (1985). Fatty acid and menaquinone analysis of actinomycetes and related organisms. In Chemical Methods in Bacterial Systematics (SAB Technical Series), pp. 173-199. Edited by M. Goodfellow \& D. E. Minnikin. London: Academic Press.

Maidak, B. L., Cole, J. R., Parker, C. T., Jr \& 10 other authors (1999). A new version of the RDP (Ribosomal Database Project). Nucleic Acids Res 27, 171-173.

Meier, A., Kirschner, P., Schröder, K.-H., Wolters, J., Kroppenstedt, R. M. \& Böttger, E. C. (1993). Mycobacterium intermedium sp. nov. Int J Syst Bacteriol 43, 204-209.

Rainey, F. A., Ward-Rainey, N., Kroppenstedt, R. M. \& Stackebrandt, E. (1996). The genus Nocardiopsis represents a phylogenetically coherent taxon and a distinct actinomycete lineage: proposal of Nocardiopsaceae fam. nov. Int J Syst Bacteriol 46, 1088-1092.

Rajan, J., Valli, K., Perkins, R. E., Sariaslani, F. S., Barns, S. M., Reysenbach, A.-L., Rehm, S., Ehringer, M. \& Pace, N. R. (1996). Mineralization of 2,4,6-trinitrophenol (picric acid): characterization and phylogenetic identification of microbial strain. J Ind Microbiol 16, 319-324.

Rosenberg, E. (2000). Hydrocarbon-oxidizing bacteria. In The Prokaryotes: an Evolving Electronic Resource for the Microbiological Community, 3rd edn, release 3.1, 20 January 2000. Edited by M. Dworkin et al. New York: Springer (http:// 141.150.157.117:8080/prokPUB/chaprender/jsp/showchap.jsp?chapnum =247\&initsec $=04 \_03$ ).

Schleifer, K. H. (1985). Analysis of the chemical composition and primary structure of murein. Methods Microbiol 18, 123-156.

Schleifer, K. H. \& Kandler, O. (1972). Peptidoglycan types of bacterial cell walls and their taxonomic implications. Bacteriol Rev 36, 407-477.

Van Hamme, J. D., Singh, A. \& Ward, O. P. (2003). Recent advances in petroleum microbiology. Microbiol Mol Biol Rev 67, 503-549.

Wayne, L. G., Brenner, D. J., Colwell, R. R. \& 9 other authors (1987). International Committee on Systematic Bacteriology. Report of the ad hoc committee on reconciliation of approaches to bacterial systematics. Int J Syst Bacteriol 37, 463-464.

Yi, H. \& Chun, J. (2004). Nocardioides ganghwensis sp. nov., isolated from tidal flat sediment. Int J Syst Evol Microbiol 54, 1295-1299.

Yoon, J.-H., Rhee, S. K., Lee, J. S., Park, Y. H. \& Lee, S. T. (1997). Nocardioides pyridinolyticus sp. nov., a pyridine-degrading bacterium isolated from the oxic zone of an oil shale column. Int J Syst Bacteriol 47, 933-938.

Yoon, J.-H., Cho, Y.-G., Lee, S. T., Suzuki, K., Nakase, T. \& Park, Y.-H. (1999). Nocardioides nitrophenolicus sp. nov., a p-nitrophenoldegrading bacterium. Int J Syst Bacteriol 49, 675-680. 
Yoon, J.-H., Kim, I.-G., Kang, K.H., Oh, T.-K. \& Park, Y.-H. (2004). Nocardioides aquiterrae sp. nov., isolated from a groundwater in Korea. Int J Syst Evol Microbiol 54, 71-75.
Zengler, K., Richnow, H. H., Roselló-Mora, R., Michaelis, W. \& Widdel, F. (1999). Methane formation from long-chain alkanes by anaerobic microorganisms. Nature 401, 266-269. 